\title{
SYSTEM REQUIREMENT ANALYSIS FOR E-LEARNING MATERIALS TO SUPPORT \\ ACADEMIC WRITING SKILLS FOR ENGINEERING STUDENTS OF VOCATIONAL HIGHER EDUCATION
}

\author{
Dita Lupita Sari \\ Politeknik Kota Malang \\ ditalupitasari@gmail.com \\ Choirun Niswatin \\ Politeknik Kota Malang \\ anis.wibisana@gmail.com
}

\begin{abstract}
This paper outlines a system requirement of proposed e-learning design for English course particularly in academic writing. However, the system requirement is focused on functional requirement. Therefore, it is necessary to carry out an intensive interaction involving systems analysts and end-users to obtain the appropriate learning materials needed by the engineering students. The instrument of this research is interview and questionnaire. The former was elaborated by the English teachers, while the latter was collected through questioners involving 32 engineering students at Politeknik Kota Malang, including the alumni. The data collection is analyzed using Kano's method. The research findings indicates that the functional requirement consists of 3 parts: (1) academic writing, (2) quizzes, and (3) writing template. The academic writing is focused on how to write abstract. Meanwhile, the quizzes cover grammar, paraphrasing, and abstract organization. This application comes with an abstract template as well, which can be downloaded and printed as required affiliation.
\end{abstract}

Keywords: system requirement, e-learning, academic writing, kano 


\section{INTRODUCTION}

The curriculum of education in Indonesia sets the English course taught since elementary school. However, the students' proficiency is still far. Writing is considered as the lowest level of proficiency. As a matter of fact, the students' ability tends to low although they are formally taught writing skills earlier in lower education level of schools (Waloyo, 2017, p. 72). Some findings of the either researches or observation indicate that students' ability in writing skill including their critical thinking through writing is poor (Setiyaningsih, 2008, p. 98).

Language learners who study English have been given writing skills as one of the cores of curriculum. Because it is one of the four skills that should be accomplished (Yamin, 2013, p. 334). The difficulties are possible to be overcome to achieve the competency. But it is different from non-English learners. Moreover, the scholars who are not English learners experience the difficulties in writing English essay, i.e. engineering students (Xiou \& Chen, 2015, p. 13). The research which encompassed the engineering students as the object of the research found that their writing skills are the lowest than other three English skills; listening, speaking and reading (Xu, 2012). However, the ability of academic writing in English language must be acquired by all students at any field of studies. Hence, their final assignments such as, thesis or dissertation could reach the wider scope of readers. Some efforts should be contended to increase the ability of academic writing among the Indonesian scholars that could be potential as the future researchers.

The ability of academic writing in Indonesia tends to be low, thus, the international publication shows very small number. Actually, the Indonesian scholars and researchers could write the publication in national as well as international level (Saubani, 2016, p. 3). Some factors affecting the low number of Indonesian contribution in global publication are likely the low level of English academic writing in terms of standardized English as well as the ungrammatical tenses (Adnan \& Zifirdaus, 2005, p. 10)

Poor academic writing is credited to the most students' opinion that learning to writing academically is very difficult (Susanti, 2013, p. 2). It is more difficult and challenging than other skills like listening, writing and reading. According to Oshima and Hogue, academic writing is difficult, indeed (Oshima \& Hogue, 1999)

The preliminary survey on engineering students at Diploma program at vocational education indicated that almost $90 \%$ of the students said that when writing abstract for their final assignment, they need to intensively consult to those good at English. The lecturers become the first person they need. So, English lectures were voted by $38 \%$ of students, followed by their final assignments' supervisor $(31.5 \%)$. In addition, they need to have consultation 3 times to have a good abstract. This raises a problem for lectures and supervisors since they must facilitate their students to give more time and efforts on top of their main duty as teachers at college such as preparing teaching, carrying out research, etc.

This research investigates the system requirement, focusing on the functional requirement of e-learning for engineering students at diploma 3 program. E-learning is a process of applying activities of communication, education, and exercises through electronic media that can be accessed anytime. Elearning enhances the quality of learning through collaborative study involving humans and technology (Sunnah \& Sukoco, 2014, p. 149). E-learning is likely to help the lectures' duty in guiding their students to write their academic writing. Therefore, it could lessen the lectures' time and work particular in writing abstract in order to do other duties such as, doing research, developing and evaluating the teaching materials, etc. This is used as a learning media to increase their ability in academic writing

\section{METHOD \\ Data Collection}

It requires having a depth needs analysis on functional requirement from the users before designing and building the soft-ware application for e-learning. Therefore, the application will meet the demand of the users'. Direct interview with the users may obtain the detailed information related to their specific needs. The data collection of this 
research was done through interview and questionnaire.

A preliminary survey was carried out to determine the functional system requirement serving as a starting point of this research. The survey aims to seek the real problems faced by the engineering students in academic writing, particularly writing abstract for their final assignment. The sampling method used in this survey is purposive sampling method. The survey questionnaires were distributed to engineering students at Politeknik Kota Malang and the alumni. These students were writing abstract in English language for final project and the alumni had left school for 2 years maximum that writing abstract in English language for the last final project before graduated. The research shared 83 questionnaires however only 35 respondents filled and submitted them. Nevertheless, 32 of filled questionnaire are considered as a valid data, but the rest of them remained invalid. The result of the survey becomes the secondary data supporting the process of the interview.

The interview was elaborated by the English lecturers based on the result of the previous survey. The result of the interview is an outline of general frame work to overcome the students' problem from the lecturers' point of view. These are a fundamental source of data to determine the functional system requirement.

Those system requirement data are analyzed to achieve the best result meeting the demands of the users. The Kano method is specifically applied to this research since this method has been widely used in research needs analysis.

\section{Kano Method}

Kano method was developed by Noriko Kano from Tokyo Riko University in 1984. This method is a model to classify the attributes of the products as well as the services. The classification is based on how well the products or services meet the customers' satisfaction (Berger et al., 1993, pp. 3-36).

See the relationship between customers' satisfaction and services or products proposed by Kano in figure 1 .

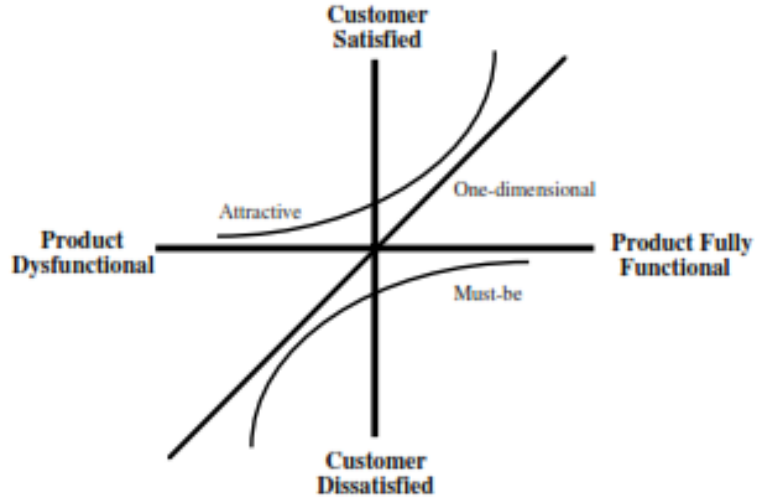

Figure 1. Kano's Diagram

The attributes are classified into several categories.

1) Attractive (excitement needs)

The greater the attributes work, the greater the level of customers' satisfaction. However, the lower attributes do not mean that they lessen the customers' satisfaction.

2) One dimensional (performance needs), The greater the attributes work, the greater the level of customers' satisfaction. In contrast, the lower the attributes, the lower the customers' satisfaction.

3) Must be (basic needs)

The customers are dissatisfied if the attributes are low, but they are never beyond the neutral. Even though, the working of the attributes are high, the customers are still disappointed. This category is the basic needs that should be fulfilled by the providers to their customers. If the providers want to increase the performance of this category, ironically, it will never significantly make the customers' satisfaction.

4) Indifferent

The products or services are never influence the customers' satisfaction, whether there are the products/services or not.

5) Reverse

This category is opposite with the one dimensional; i.e. the level of customers' satisfaction is higher if the services or products are not the way they are. 
6) Questionable

This category occurs when the customers are satisfied or dissatisfied sometimes if there are/ not services or products

The questionnaire of this research is adapted from Kano method. The questions consist of optional criteria covering like, must be, neutral, live with, and dislike. Each question is positive and negative. The responses are combined with the table of Kano evaluation as seen in Table 1, hence there is appropriateness between functional and customer requirements.

From the Table 1, it could be concluded that each of question is counted in one of the following criteria:

$$
\begin{aligned}
& \mathrm{A}=\text { Attractive } \\
& \mathrm{M}=\text { Must }- \text { Be } \\
& \mathrm{O}=\text { One-Dimensional } \\
& \mathrm{R}=\text { Reverse } \\
& \mathrm{Q}=\text { Questionable } \\
& \mathrm{I}=\text { Indifferent }
\end{aligned}
$$

The result of the Kano evaluation table will determine Kano categorization in every attribute using the following formula.

1. If (one dimensional + attractive + must be) $>$ (indifferent + reserve + questionable), the maximum grade is (one dimensional, attractive, must be).

2. If (one dimensional + attractive + must be) $<$ (indifferent + reserve +questionable), the maximum grade is (indifferent, reserve, questionable)

After determining the Kano categorization, it subsequently seeks the value of better and worse. Better indicates how high the customers' satisfaction is if the features are provided (A\&O). Conversely, Worse indicates how low the customers' satisfactions is if the features are not provided. To obtain the value of Better and Worse, the following formula is used:

Better $=\frac{A+O}{A+O+M+I}$

Worse $=\frac{O+M}{A+O+M+I}$

\section{FINDINGS AND DISCUSSION}

\section{Data Collection}

The preliminary survey found that the problem faced by most of the engineering students in writing abstract is composing the abstract particularly constructing the words into sentences as well as the abstract structure (70\%). The following problem is grammar $(15.7 \%)$ and vocabulary (14.3\%).

Those data help the interview process involving English lecturers. After interview, the system requirements of e-learning can be concluded:

1. The system provides the learning materials of academic writing.

2. The system provides the exercises as well as the quizzes to drill the grammar.

3. The system provides the exercises and quizzes to practice constructing the sentences and paraphrasing using their own words.

4. The system provides the template for constructing abstract aiming to help the students in composing the structure abstract.

5. The system provides printing menu to

\begin{tabular}{|c|c|c|c|c|c|c|}
\hline \multicolumn{2}{|c|}{ Customer Requirements } & \multicolumn{5}{|c|}{ Dysfunctional } \\
\hline & & 1 & 2 & 3 & 4 & 5 \\
\hline \multirow{6}{*}{ Functional } & & & & & & \\
\hline & 1. like & Q & A & A & A & $\mathrm{O}$ \\
\hline & 2. must-be & $\mathrm{R}$ & I & I & I & M \\
\hline & 3. neutral & $\mathrm{R}$ & I & I & I & M \\
\hline & 4. live with & $\mathrm{R}$ & I & I & I & M \\
\hline & 5. dislike & $\mathrm{R}$ & $\mathrm{R}$ & $\mathrm{R}$ & $\mathrm{R}$ & Q \\
\hline
\end{tabular}
print the document, which has been displayed in template

6. The system provides the security system with the login menu for every user

Table 1. Table of Kano Evaluation 
The functional needs mentioned above are the main questions in the survey distributed to the engineering students. The objective of distributing the survey is to obtain the functional system between the system requirements and the users. The list of the questions in survey refers to Kano method.

\section{Determining of Kano categorization}

The data collection from the questionnaire is analyzed using table of Kano evaluation. This table determines Kano categorization. The result of data analysis can be seen in Table 2, Table 3, Table 4, Table 5, Table 6 and Table 7.

Table 2. Table of Kano Evaluation on Functional Requirement 1

\begin{tabular}{lccccc}
\hline & \multicolumn{5}{c}{ Dysfunctional } \\
Functional & 1 & 2 & 3 & 4 & 5 \\
\hline 1 (like) & (must be) & (neutral) & (live with) & (dislike) \\
2 (must be) & 4 & 1 & 0 & 3 & 7 \\
3 (neutral) & 0 & 0 & 2 & 0 & 9 \\
4 (live with) & 0 & 0 & 0 & 1 & 1 \\
5 (dislike) & 0 & 0 & 0 & 0 & 0 \\
\hline
\end{tabular}

Table 3. Table of Kano Evaluation on Functional Requirement 2

\begin{tabular}{lccccc}
\hline & \multicolumn{5}{c}{ Dysfunctional } \\
Functional & 1 & 2 & 3 & 4 & 5 \\
(like) & (must be) & (neutral) & (live with) & (dislike) \\
\hline (like) & 2 & 1 & 4 & 0 & 12 \\
2 (must be) & 1 & 0 & 0 & 3 & 5 \\
3 (neutral) & 0 & 0 & 1 & 0 & 0 \\
4 (live with) & 0 & 0 & 0 & 2 & 1 \\
5 (dislike) & 0 & 0 & 0 & 0 & 0 \\
\hline
\end{tabular}

Table 4. Table of Kano Evaluation on Functional Requirement 3

\begin{tabular}{lccccc}
\hline & \multicolumn{5}{c}{ Dysfunctional } \\
Functional & 1 & 2 & 3 & 4 & 5 \\
(like) & (must be) & (neutral) & (live with) & (dislike) \\
\hline (like) & 2 & 0 & 3 & 3 & 11 \\
2 (must be) & 1 & 0 & 0 & 0 & 3 \\
3 (neutral) & 1 & 0 & 0 & 0 & 0 \\
4 (live with) & 0 & 1 & 2 & 2 & 3 \\
5 (dislike) & 0 & 0 & 0 & 0 & 0 \\
\hline
\end{tabular}

Table 5. Table of Kano Evaluation on Functional Requirement 4

\begin{tabular}{lccccc}
\hline & \multicolumn{5}{c}{ Dysfunctional } \\
Functional & 1 & 2 & 3 & 4 & 5 \\
\hline 1 (like) & (must be) & (neutral) & (live with) & (dislike) \\
2 (must be) & 1 & 0 & 2 & 2 & 11 \\
3 (neutral) & 0 & 0 & 3 & 0 & 0 \\
4 (live with) & 0 & 0 & 0 & 0 & 3 \\
5 (dislike) & 0 & 1 & 1 & 0 & 0 \\
\hline
\end{tabular}

Table 6. Table of Kano Evaluation on Functional Requirement 5

\begin{tabular}{lccccc}
\hline & \multicolumn{5}{c}{ Dysfunctional } \\
Functional & 1 & 2 & 3 & 4 & 5 \\
\hline 1 (like) & (must be) & (neutral) & (live with) & (dislike) \\
2 (must be) & 2 & 1 & 0 & 3 & 7 \\
3 (neutral) & 0 & 0 & 0 & 2 & 4 \\
4 (live with) & 0 & 0 & 1 & 1 & 1 \\
5 (dislike) & 0 & 0 & 0 & 0 & 0 \\
\hline
\end{tabular}

Table 7. Table of Kano Evaluation on Functional Requirement 6

\begin{tabular}{lccccc}
\hline & \multicolumn{5}{c}{ Dysfunctional } \\
Functional & $\begin{array}{c}\text { (like) } \\
\text { (must be) }\end{array}$ & $\begin{array}{c}\text { (neutral) } \\
\text { (live with) }\end{array}$ & (dislike) \\
\hline (like) & 1 & 0 & 3 & 1 & 7 \\
2 (must be) & 0 & 1 & 0 & 1 & 6 \\
3 (neutral) & 0 & 0 & 3 & 0 & 0 \\
4 (live with) & 0 & 0 & 1 & 2 & 4 \\
5 (dislike) & 2 & 0 & 0 & 0 & 0 \\
\hline
\end{tabular}

The result of Kano evaluation then used for determining the Kano categorization on each attribute. These can be seen in Table 8 .

The result of determining Kano categorization indicates that functional requirement is on the One dimensional and Must be. The One dimensional indicates that the higher the customers' satisfaction, the higher the functional requirement attributes in the system. In contrast, the lower the customers' satisfaction, the lower the functional requirement attributes in the system. This means that the available and the better attributes increase the better customers' satisfaction and vise verse. One dimensional is clearly indicated by the functional requirement no. 2, 3, 4, and 5 . 
Table 8. Result of Kano Categorization Determiner

\begin{tabular}{ccccccccccc}
\hline $\begin{array}{c}\text { Functional } \\
\text { Requirements }\end{array}$ & $\mathrm{A}$ & $\mathrm{M}$ & $\mathrm{R}$ & $\mathrm{O}$ & $\mathrm{Q}$ & $\mathrm{I}$ & $\mathrm{O}+\mathrm{A}+\mathrm{M}$ & $\mathrm{I}+\mathrm{R}+\mathrm{Q}$ & Total & $\begin{array}{c}\text { Kano } \\
\text { Categorization }\end{array}$ \\
\hline 1 & 4 & 10 & 0 & 7 & 4 & 7 & 21 & 11 & 32 & $\mathrm{M}$ \\
2 & 5 & 6 & 1 & 12 & 2 & 6 & 23 & 9 & 32 & $\mathrm{O}$ \\
3 & 6 & 6 & 2 & 11 & 2 & 5 & 23 & 9 & 32 & $\mathrm{O}$ \\
4 & 4 & 10 & 3 & 11 & 1 & 3 & 25 & 7 & 32 & $\mathrm{O}$ \\
5 & 4 & 6 & 0 & 7 & 2 & 13 & 17 & 15 & 32 & $\mathrm{O}$ \\
6 & 4 & 10 & 2 & 7 & 1 & 8 & 21 & 11 & 32 & $\mathrm{M}$ \\
\hline
\end{tabular}

Meanwhile, Must be indicates that the customers are dissatisfied if the events of system attributes are low. Surprisingly, the customers' satisfaction is not beyond the neutral although the events of the system attributes reach higher. Must be is indicated by functional requirement no 1 and 6.

\section{Measurement of Kano Method}

The result of determiner Kano categorization is then calculated obtaining the value of better and worse. Better indicates how high the customers' satisfaction is if the features $(\mathrm{A} \& \mathrm{O})$ are provided. Whereas, Worse indicates how low the customers' satisfaction is if those features $(\mathrm{O} \& \mathrm{M})$ are not provided. The value of better and worse are seen in the Table 9.

Table 9. Measurement Kano Method

\begin{tabular}{ccccccc}
\hline $\begin{array}{l}\text { Functional } \\
\text { Requirement }\end{array}$ & A & M & O & I & Better & Worse \\
\hline 1 & 4 & 10 & 7 & 7 & 0.39 & 0.61 \\
2 & 5 & 6 & 12 & 6 & 0.59 & 0.62 \\
3 & 6 & 6 & 11 & 5 & 0.61 & 0.61 \\
4 & 4 & 10 & 11 & 3 & 0.54 & 0.75 \\
5 & 4 & 6 & 7 & 13 & 0.37 & 0.43 \\
6 & 4 & 10 & 7 & 8 & 0.38 & 0.59 \\
\hline
\end{tabular}

The measurement of Kano method in Table 9 indicates that the highest value of better is on the attributes no 3 . This means that the available of the third attributes considerably makes the customers feel satisfied. On the other hand, the highest value of worse is on the no. 4. This highlights that the customers will be extremely dissatisfied.

\section{CONCLUSION}

Based on the result of system functional requirement of e-learning using Kano method, it is found that system functional requirement meets the users' need.

In Kano categorization, users demand that the systems cover quizzes/exercise on grammar, paraphrase, template for composing abstract, and print menu to print the file of abstract which has been composed. If these four attributes are not provided, the customers are greatly dissatisfied. Nevertheless, if the two attributes of this system; theory on how to write abstract along with the security system of login, which are even needed by the users are not provided, they will not make the users disappointed. In other words, these attributes may be or may not be provided, they will not be a big deal for the users.

The value better and worse indicates that the quizzes or exercises to drill the paraphrasing makes the users greatly satisfied. On the contrary, if the attributes of template for composing abstract is not provided, the users will be extremely dissatisfied.

\section{REFERENCES}

Adnan, Z., \& Zifirdaus, I. (2005). Merebut hati audiens internasional. Jakarta: PT. Gramedia Pustaka Utama

Berger, C., Blauth, R., Bolster, C., Burchill, G., DuMouchel, W., Pouliot, F., ... Walden, D. (1993). Kano's methods for understanding customer-defined quality. The Center for Quality Management Journal, 2(4), 33-36.

Oshima, A., \& Hogue, A. (1999). Writing academic english; (3rd.). United States of America: Pearson. 
Saubani, A. (2016) Jumlah peneliti dan publikasi penelitian masih rendah. Koran Republika, edisi 3 Maret 2016

Setiyaningsih, Y. (2008). Peningkatan kemampuan menulis argumentatif dan keterampilan berpikir kritis berbahasa indonesia mahasiswa melalui model pembelajaran berdasarkan logika toulmin. EDUCATIONIST, (II)2.

Sunnah A, Sukoco. (2014). Evaluasi pelaksanaan program Seamolec di SMK daerah istimewa yogyakarta. Jurnal Pendidikan Vokasi, (4)2. Retrieved from https://journal.uny.ac.id/index.php/jpv/ar ticle/view/2542

Susanti, A. (2013). Pengembangan model pembelajaran kooperatif tipe CIRC untuk meningkatkan kemampuan menulis bahasa Inggris mahasiswa D3 administrasi negara FIS UNESA. Retrieved from http://ejournal.unesa.ac.id/article/7950/9 0/article.pdf

Waloyo, E. (2017). The implementation of mind mapping technique in teaching writing: A case study at MAN 13 Jakarta. ELT-Echo, (2)1.

Yamin, M. (2013). Improving writing example essays of the fifth semester students in the english department of fkip unlam through process-writing technique. Cendekia,(11)2.

Xiou, G., \& Chen, X. (2015). English academic writing difficulties of engineering students at tertiary level in China. World Transaction on Engineering and Technology Education, (13)3.

Xu, F. (2012). Teaching and researching english writing. Beijing: Foreign Language Teaching and Research Press. 